\title{
犬ブルセラ症が発生した犬繁殖場における 抗菌剂投与による抗体価の変動
}

\author{
相馬武久 ${ }^{1 \dagger} \quad$ 河口雅登 ${ }^{1)} \quad$ 勝川千尋 ${ }^{2)}$ \\ 1）マルピー・ライフテック(株)臨床検査部（テ 563-0011＼cjkstart池田市伏尾町 103） \\ 2）大阪府立公衆衛生研究所感染症部（５37-0025 大阪市東成区中道 1-3-69）
}

(2012 年 7 月 26 日受付 $\cdot 2012$ 年 9 月 18 日受理)

\begin{abstract}
要
約

犬ブルセラ症が発生した犬繁殖場に打いてマイクロタイター凝集反応（MA）とELISAにより抗Brucella canis 抗体 が検出された 14 頭を抗体陰性犬と隔離した上で塩酸ドキシサイクリンとマルボフロキサシンを投与したところ, 両抗 体の陽性率は投薬開始後 8 週間目まで低下したが，16 週間目にはMA，ELISAそれぞれ $27.3 \% ， 63.6 \%$ に昇した。 この成績は本症の治療効果監視のための抗体検査の有用性並びにELISAの高い検出感度を示すものである，一方，抗 体陰性犬 66 頭について塩酸ドキシサイクリンを単郕投与したが, 観察期間の 32 週間に両抗体ともに陰性に推移した. このことから感染犬の隔離や施設内の消毒など適切な対応をすれば, 抗体陰性犬に対してテトラサイクリン系の単剂投 与であっても十分な予防効果が得られると考えられた.

——ーワード: 抗菌剤, 抗体, 犬繁殖施設, 犬ブルセラ症, PCR.
\end{abstract}

日獣会誌 $66 ， 115 １ 20 （ 2013 ）$

犬ブルセラ症はグラム陰性の小型短桿菌である犬流産 菌（Brucella canis）の感染に起因する犬の代表的な生 殖器感染症で, 雌での流産と雄での精巣炎や不妊症を主 徵とする. 本菌は1960 年代後半に米国で増加した繁殖 障害の犬から証明され [1]，わが国では 1972 年に静岡 県のビーグル犬からはじめて認められている $[2]$. 本症 は近年でも全国各地で集団発生が見られており $[3,4]$ ， わが国の繁殖施設における最も重要な感染症の一つとし て認識されている。 また, 本症は人獣共通感染症の一つ でもあり, 人での症状は一般的に軽度であるものの主に 実験従事者, 獣医師及び飼育管理者で散発的に発生が報 告されている $[5-7]$.

わが国に扔けるB. canisの感染率は一般家庭で個人的 に飼育されている犬では $1 \%$ 未満ときわめて低いが $[8$, 9], 繁殖施設, 愛護センターなど多頭数を飼育する所に 本菌の侵入があった場合, 犬でのその感染率は大幅に増 加する $[3,10]$.このため, 本菌の侵入を許した施設で は臨床的及び経済的被害は無論のこと, 公衆衛生学的に も早急な衛生対応が要求される.
B. canisが侵入した施設での対策として感染犬の隔 離，排除や施設内の消毒に加えて抗菌剤の投与が推奖さ れている $[3,11]$. しかし，投薬の効果は限定的で，必 ずしも感染を終結させるものではないことから $[5,11]$ ， 治療後の感染状況を監視することが好ましいと考えられ る.

B. canis 感染の診断のために抗体検查, PCR どの 遺伝子検查及び菌分離があげられるが $[5]$ ，臨床的には 迅速性やコストの面で抗体検査が最も頻繁に利用されて いる.これまで本症の診断や B. canis 感染犬の疫学調査 のために本菌に対する抗体検查を利用した成績は多く見 られるが，筆者らの知り得るかぎり治療効果の確認のた めに抗体検查を供した成績はほとんど報告されていな い.

今回，われわれは犬繁殖施設においてブルセラ症の突 然発生に遭遇した. そこで, 本研究ではB. canis 感染に 対する抗菌剂の効果のモニタリングとしての本菌に対す る抗体検查の有用性を知るために，本施設の飼育犬に対 して抗菌剤を投与し，その後の抗体価の変動を検討し

$\dagger$ 連絡責任者：相馬武久 (マルピー・ライフテック(侏)臨床検査部)

テ 563-0011 池田市伏尾町 103 072-753-0335 FAX 072-754-2208

E-mail : takehisa-soma@ds-pharma.co.jp

—115-日獣会誌 $66 \quad 115 \sim 120 \quad(2013)$ 
た。

近年B. canis 感染犬の治療剂としてフルオロキノロ ン系抗菌剂が効果的であることが報告されているが $[5$, 12, 13], in vivoでの成績はいまだデー夕は不足してい る. そこで, 本研究では本系抗菌剤の一つで, 近年小動 物への処方の機会が増えているマルボフロキサシンを抗 B. canis 抗体陽性犬に投与し，その効果も合わせて検討 した.

\section{材料及び方法}

症例及び検查材料：2010 年 3 月に京都府の愛玩犬繁 殖施設で繁殖用犬の雄 27 頭中 3 頭で精巣炎，雌 53 頭中 2 頭で死流産が観察された。このため，これら 5 頭を含 む本施設の繁殖犬全 80 頭から血清及びEDTA-2K 処理 抗凝固全血材料を採取し，それぞれを供試してマイクロ タイタ一凝集反応 (MA) とELISAによる抗B. canis 抗 体測定及び PCRによるB. canis 遺伝子の検出を実施し た（検查方法の詳細については後述する）。抗体陽性例 （雄 5 頭，雌 9 頭，合計 14 頭）に対して去勢または避妊 処置を施すとともに，抗体陰性例とは隔離管理し，全頭 に対して抗菌剂投与を実施した。まず全頭に塩酸ドキシ サイクリン（ファイザー(侏，東京） $10 〜 15 \mathrm{mg} / \mathrm{kg}$ ， SID（1 日 1 回）で 2 週間，さらにBID（1日 2 回）で 2 週間経口投与した。引引続き抗体陰性犬に対しては本剤 $10 \sim 15 \mathrm{mg} / \mathrm{kg}$ ，BID で 4 週間経口投与した。一方，抗 体陽性犬に対して本剤 $10 \sim 15 \mathrm{mg} / \mathrm{kg} ，$ BID に加えてマ ルボフロキサシン（ファイザー(侏)，東京）を 3 〜 $5 \mathrm{mg} / \mathrm{kg}$ ，SID で 4 週間経口投与した．さらに投薬後に 抗体の再上昇が認められた例に対して再度, 塩酸ドキシ サイクリン及びマルボフロキサシンを上記と同じ用法, 容量で 6 週間経口投与した。抗菌剂投与開始後 $4,8,16$ 及び 32 週間目に血清材料を採取し, 抗体検查を実施し た。また，中性電解水（アサヒプリテック侏，神戸）で 本施設内及び隔離施設内の消毒を治療開始から 16 週間 毎日実施した。

抗体検查：MA と ELISAにより血清中の抗 B. canis 抗体を測定した．MAは既報 $[14,15]$ に従い実施した。 すなわち，96ウエルU字プレートにてリン酸緩衝食塩 液（PBS）で1：10 から 2 倍段階希採した血清 $50 \mu$ lに B. canis $\mathrm{QE}-13 \mathrm{~B}$ 株加熱不活化菌液 (北里研究所, 埼玉) を等量加え, 混和後 $50{ }^{\circ} \mathrm{C}$ で一晚静置した。 その後, プ レートを観察し，凝集を示す最高の血清希䣋倍率を凝集 価（MA 価）とし，1：160 以上を抗体陽性と判定した. ELISA は加熱抽出抗原を用いて実施した [16]．すなわ ち, B. canis 加熱不活化菌液（同上）をPBS で 3 回洗浄 し，その沈渣をPBSに懸濁し， $120^{\circ} \mathrm{C} ， 20$ 分間加熱処 理した。その後， $3,500 \mathrm{~g} ， 10$ 分間遠心した上清液を抗 原とした。10mM 炭酸緩衝液（pH9.7）で調整した抗原
液を 96 ウエル ELISA用プレートに $50 \mu \mathrm{l} /$ ウエル分注し た. $37^{\circ} \mathrm{C} て ゙ 1$ 時間吸着後，ブロッキング溶液（ブロック エース，DSファーマバイオメディカル侏，大阪）を分 注し， $37^{\circ} \mathrm{C} て ゙ 1$ 時間放置した。この固相化プレートに $1 \%$ 牛血清アルブミン加PBS で 1：1,000 に希积された 血清を $50 \mu \mathrm{l} /$ ウエル分注した。 $37{ }^{\circ} \mathrm{C} 1$ 時間反応後, Tween 20 加 PBS (PBST) で 3 回洗浄, ペルオキシダ 一ゼ標識ヤギ抗犬 IgG 抗体 $(\mathrm{H}+\mathrm{L})$ （Jackson Immuno Research, U.S.A.）を $50 \mu l /$ ウエル分注し， $37^{\circ} \mathrm{C} 1$ 時間 反応させた.PBSTで 3 回洗浄後, $0.2 \mathrm{M}$ ABTS加クエ ン酸緩衝液を $100 \mu \mathrm{l} /$ ウエル分注した。 $37^{\circ} \mathrm{C} 15$ 分間反 応後， $405 \mathrm{~nm}$ で吸光度（ELISA 価）を測定した. カッ トオフ值の設定は既報［17］を採用した，すなわち，非 免疫 SPF ビーグル犬 119 頭の ELISA 価（平均值士標準 偏差 $=0.102 \pm 0.046 ）$ で得られた最高值（0.232）の 1.5 倍（0.348）に設定し，この值以上を抗体陽性と判定 した.

PCR：Brucella spp.のvirB2 遺伝子を検出するプラ イマーペアを用いてNested PCR [18］で実施した。す なわち，抗凝固処理全血から DNA 精製キット（株キア ゲン，東京）を用いてDNAを精製した。この精製物を B2F-B2R プライマーペア各 $0.4 \mu \mathrm{M}, 0.2 \mathrm{mM}$ dNTPs, 1.5U DNA ポリメラーゼ (Applied Biosystems, U.S.A.) を含む混合液に加え， $95{ }^{\circ} \mathrm{C} 5$ 分間反応後，変性 $94{ }^{\circ} \mathrm{C} 1$ 分間，アニーリング $52{ }^{\circ} \mathrm{C} 1$ 分間，伸張 $72{ }^{\circ} \mathrm{C} 1$ 分間の反 応を 40 サイクル行い，最後に $72{ }^{\circ} \mathrm{C} 5$ 分間反応させた. この反応液を $\mathrm{B} 2 \mathrm{~N}-1-\mathrm{B} 2 \mathrm{~N}-2$ プライマーペアを含む混 合液（組成は B $2 \mathrm{~F}-\mathrm{B} 2 \mathrm{R}$ プライマーペアと同じ）に加 え，同条件で反応させた，PCR 産物にローディングバ ッファーを加え，2\%アガロースゲルにアプライし， $100 \mathrm{~V}$ で約 30 分間泳動した。DNA バンドを可視化する ためにゲルをエチジウムブロミド溶液に浸漬し，紫外線 下で280bp の産物を観察した。

\section{成績}

表に示すように 14 頭，14頭，2頭でそれぞれ MA 抗 体，ELISA抗体，PCRが陽性と判定された。このこと は本施設への B. canis の浸潤を示すもので，有症犬が犬 ブルセラ症に罹患していたものと思われた。な抢，MA 抗体陽性例と ELISA 抗体陽性例は同一個体であった。 全 80 頭中 2 頭（2.5\%）が陽性であったPCRの結果は 抗体検查 $(14 / 80 ; 17.5 \%)$ と比較すると有意に低い值 であった（ $\left.\chi^{2}=10.00, P=0.0016\right) . P C R$ 陽性の 2 頭 はともに臨床症状は観察されておらず，このうちの 1 頭 は抗体陰性であった，その後の 32 週間の観察期間中に MA 抗体, ELISA 抗体ともに陽転することはなく，臨床 症状の発現も観察されなかった。

そこで，14頭の抗体陽性例について投薬開始後の MA 
相馬武久 河口雅登 勝川千尋

表 抗 Brucella canis 抗体検査と PCR の比較

\begin{tabular}{ccrc}
\hline \hline & & \multicolumn{3}{c}{ 抗体検查 } \\
\cline { 3 - 4 } & & + & - \\
\hline \multirow{2}{*}{ PCR } & + & 1 & 1 \\
& - & 13 & 65 \\
\hline
\end{tabular}

投薬前の 80 頭での成績を示す.

抗体検查は MA 価, ELISA 価それぞれ 1：160 以上, 0.348 以上を陽性と判定した.

抗体及びELISA抗体の陽性率の経時変化を検討したと ころ（投薬開始後 $4 ， 8 ， 16$ 週間目それぞれ $14 ， 14 ， 11$ 頭), 図 1 に示すように投薬開始後両者とも低下したが, 16 週間目にかけて陽性率が上昇を示した。そして，有 意差は示されなかったものの $(P>0.05)$, ELISA抗体 の陽性率 $(7 / 11 ; 63.6 \%)$ は MA抗体 $(3 / 11 ; 27.3 \%)$ に比べて上昇傾向にあった。な押，投薬開始後 8,16 週 間目では MA 抗体陰性でELISA抗体陽性の例がそれぞ れ3 頭 $(21.4 \%), 4$ 頭 $(36.4 \%)$ 観察されたが，MA抗 体陽性でELISA 抗体陰性の例は検出されなかった。一 方，投薬前に抗体陰性であった例について検討したとこ 万(投薬開始後 $4 ， 8 ， 16 ， 32$ 週間目それぞれ 66,62 , 61，51 頭)，PCR 陽性であった 1 頭を含む全頭で 32 週 間の観察期間中 MA 抗体, ELISA 抗体ともに陰性のレ ベルで推移した（データ示さず）.

さらに，投薬前に抗体陽性であった例について投薬開 始後のMA 価とELISA 価の変動を検討したところ，図2 に示すように両価ともに平均值で投薬開始後 8 週間目ま で低下を示した。その後 MA 価は16 週目にかけてほぼ 同じレベルで推移したのに対してELISA 価は上昇傾向 に転じた。そこで，個体ごとに変動を見たところ（図 3)，3 頭が 16 週間目にMA価，ELISA価ともに上昇を 示した $(t$ 検定により 8 と 16 週間目の ELISA 価の間に 有意差あり； $P=0.0362)$. なお，他の 2 頭において ELISA 価のみが若干の上昇傾向を示した（データ示さ ず)。このため，前者の 3 頭に対して抗菌剂の再投与を 実施したが，3頭ともに再投与の 16 週間後（初回投薬開 始後 32 週間目）の検查では両抗体価の低下が認められ た（図 3）（t検定により 16 と 32 週間目の MA 価の間に 有意差あり； $P=0.0198)$ 。な抢，後者の 2 頭については 再投与を実施しなかった。

\section{考察}

抗B. canis 抗体陽性犬の MA と ELISA の抗体価並び 抗体陽性率はともに投薬開始後速やかに低下を示した. この抗体価の変動は既報 [12］ともほぼ一致している. しかしながら，B. canisは細胞内寄生性のため治療の効 果が限定的で，菌血症終結に伴い抗体が陰転しても組織 内で生存している場合があることから，抗菌剤の投与終

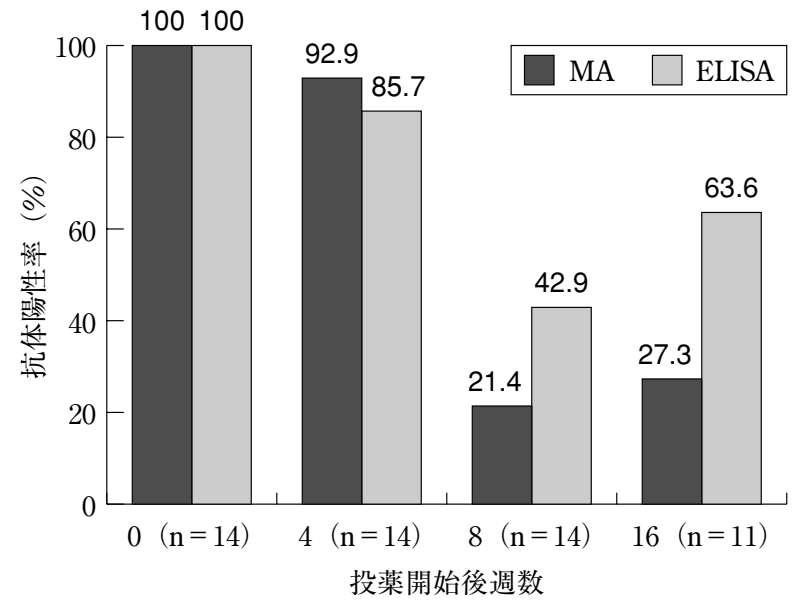

図 1 抗Brucella canis 抗体陽性例での投薬開始後の抗体 陽性率の変動

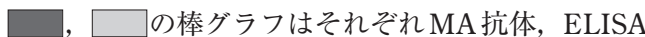
抗体の陽性率を示す. 投薬前 (0 週) 及び開始後 $4,8,16$ 週間目それぞれ 14, 14, 14, 11頭の血清を供試した。

了後に感染が再燃することが比較的頻繁に起こるといわ れている $[11,19]$. 本研究に打いても投薬開始後一旦 低下した抗体価が 16 週間目（投薬終了 10 週間後）には MA 価，ELISA 価がそれぞれ 3 頭 $(27.3 \%) ， 5$ 頭 (45.5\%) で上昇に転じ，本感染の再燃が強く疑われた。 そこで，MA価，ELISA価がともに上昇した 3 頭につい て抗菌剤の再投与を行ったところ， 3 頭とも両価が再度 低下を示した．以上の成績から B. canis 感染に対する治 療効果監視のために抗体検查が有用であるとともに，塩 酸ドキシサイクリンとマルボフロキサシンの併用による 本感染症に対する一定の効果が認められた。

本研究において投薬前の検査ではMA と ELISAの定 性的な結果は一致したが，投薬開始後 8 及び 16 週間目 にはそれぞれ 3 頭，4頭がMA抗体陰性にもかかわらず ELISA 抗体陽性と，ELISAがMAに比べて高感度に抗 体を検出する傾向がみられた。この要因としてMAなと 凝集反応は打もに菌体のリポ多糖体に対する抗体を検出 するのに対して今回採用した加熱抽出抗原を用いた ELISA はリポ多糖体だけでなく，その他の菌体外膜に 対する抗体にも反応すること $[20,21]$ ，さらに慢性期 や再感染に扩ける IgM の減少や非凝集抗体の存在 $[22$, 23]苼元られる。このことから特に慢性期や治療効果 確認のための抗体検查として凝集反応だけでなく ELISA などょり高感度の検查を併用する必要があるも のと考えられる。

一方，投薬前に抗体陰性であった例はその後検查でき た全頭で 32 週間の観察期間中にMA抗体，ELISA 抗体 とも陰性のレベルで推移し，感染を防御できたものと推 測する。また，抗体陰性犬の 1 頭で PCRにより血中か ら B. canis 遺伝子が検出されたにもかかわらず，32 週 

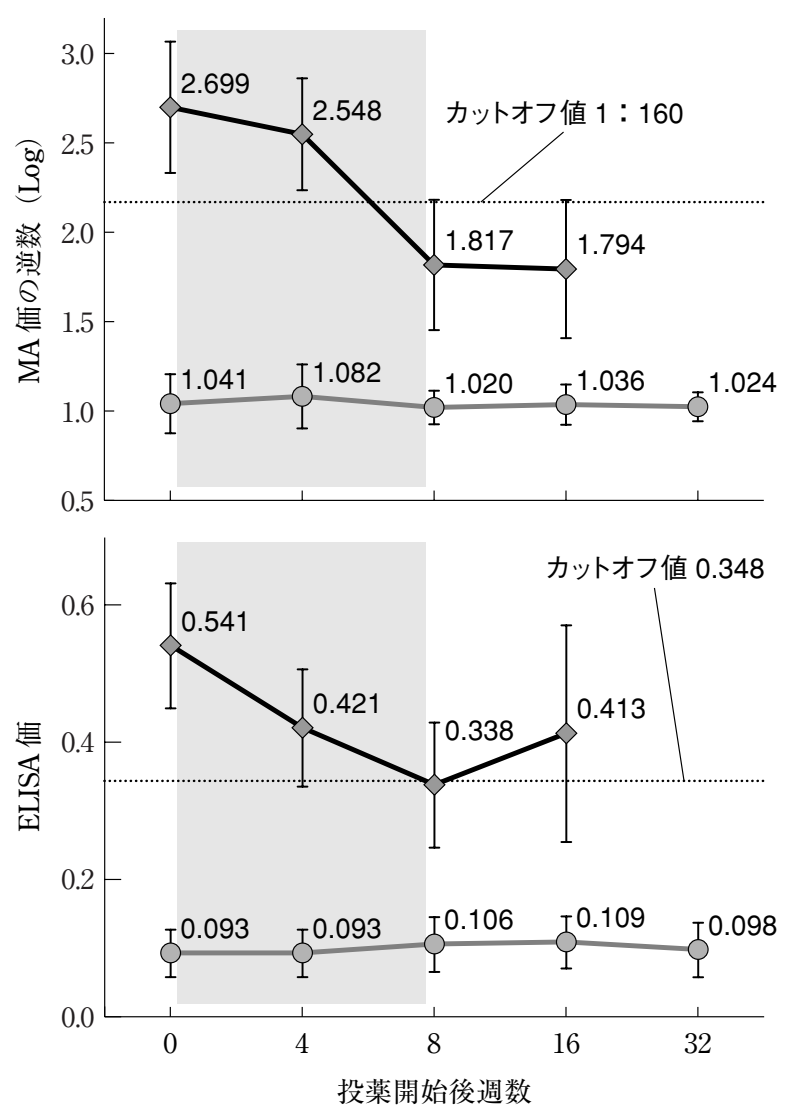

図2 抗菌剂投与による抗Brucella canis 抗体価の変動 上図，下図はそれぞれMA価，ELISA 価を示す。 MAについてはMA価の逆数の対数值を検討した.ま た，検出の下限（1：20）未満については便宜上 1 ： 10 とした。 ○印，○印はそれぞれ投薬前に抗体陽性， 陰性であった例の平均值, 縦棒は標準偏差を示 す. $\square$ 部分は抗菌剂の投与期間 (8 週間) を示す. 投薬前に抗体陽性であった例は投薬開始前, 開始後 4 , 8，16 週間目それぞれ $14,14,14,11$ 頭の血清を， 抗体陰性であった例は投薬開始後 $4,8,16,32$ 週間 目にそれぞれ $66 ， 62 ， 61 ， 51$ 頭の血清を供試した。 投薬開始後 16 週間目にMA，ELISA 両抗体価の上昇 を示した初回抗体陽性例 3 頭について抗菌剤の再投与 を実施し，32 週間目に抗体検査を実施した。

間の観察期間中に抗体価の上昇が示されなかった。この 犬は隔離飼育されることなく，他の抗体陰性犬と同じ部 屋で飼育されていた。 しかし，本研究の成績を見るかぎ り同居犬への感染の伝播についても認められていない. おそらく，この犬は感染の初期段階であったため，持続 感染が成立しやすい生殖器組織 $[5,19]$ に感染する前 に抗菌剂投与により効果的に本菌を排除することができ たと考えられる.そして, 今回の成績でB. canisの感染 に対して抗体検査に比べて PCRの検出感度が著しく低 かったことを考慮すると，この犬以外にも感染初期で抗 体が検出されなかったものが存在し, 同様に抗菌剂の投 与により本菌が排除されていたことが予想される．以上 のことから，抗体検査は感染初期（感染後 $2 \sim 4$ 週間）
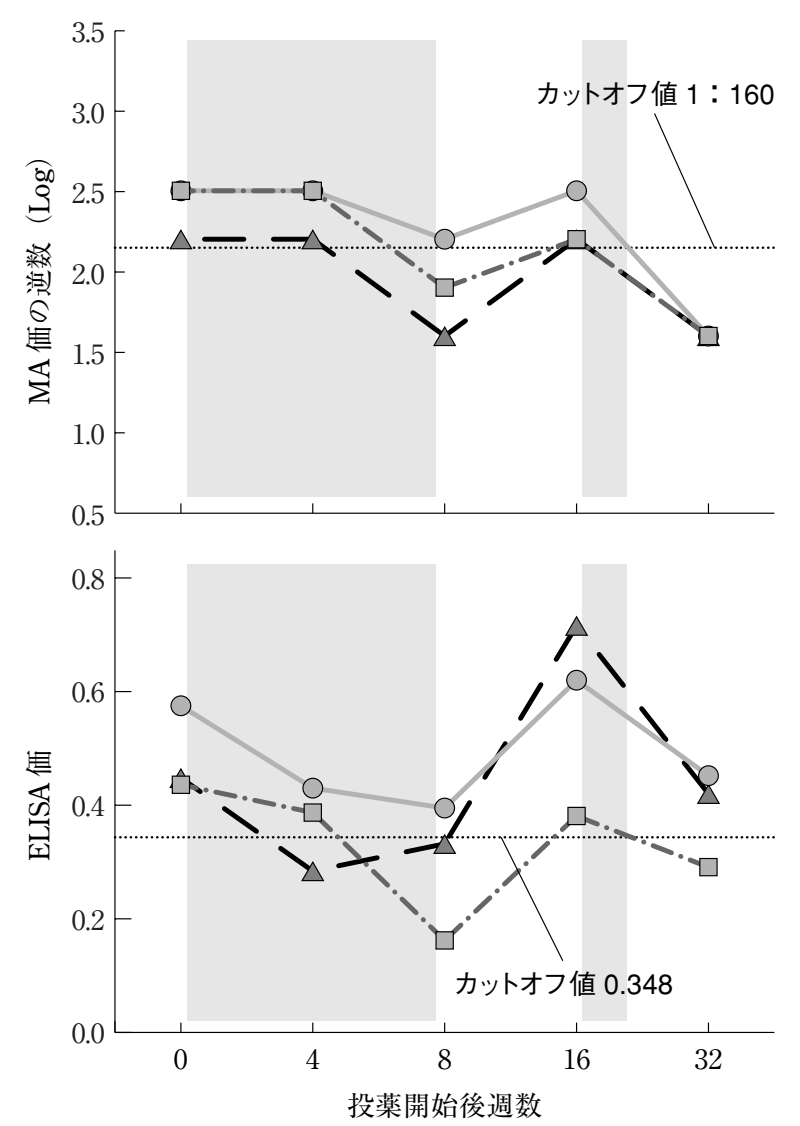

図3 抗Brucella canis 抗体価が再上昇した例での抗体価 の変動

投薬開始後 16 週間目にMA，ELISA 両抗体価の上 昇を示した初回抗体陽性例 3 頭について抗菌剤の再投 与を実施し，32 週間目に抗体検査を実施した。上図， 下図はそれぞれ MA価，ELISA 価を示す１6 週間目 にMA，ELISA 両価が上昇した 3 頭に抗菌剤を再投与 し，32 週間目に抗体検查を実施した.MAについては MA 価の逆数の対数值を検討した. $\square$ 部分は抗菌剂 の投与期間（前半，後半それぞれ 8,6 週間）を示す.

$[5,11,24]$ では偽陰性の結果となる可能性があるもの の，陽性犬が確認された場合に全頭への速やかな予防的 投薬を実施するのであれば，定期的な抗体検査は繁殖施 設における本症の防疫のために有効な手段の一つである と思われる。

犬ブルセラ症の治療に対して一般的には単剂投与は効 果的ではないと認識されている $[5,11,19]$. 今回，抗 体陽性犬に対しては 2 剤の併用であっても必ずしも完全 な治療効果は得られなかったが, 抗体陰性犬に対しては 塩酸ドキシサイクリンの単剂投与で感染を阻止すること ができた。これまでにミノサイクリンの単剤投与でも本 感染に対する効果が示唆されており [4]，これらのこと から判断すると感染犬の速やかな排除と施設内の消毒な ど適切な対応を実施すれば，少なくとも抗体㓌性犬に対 して安価で経口投与が可能であるテトラサイクリン系の 単剂投与であっても十分な予防的な効果が期待できるも 
のと思われる。

今回のような商業施設の犬に対しては家庭犬に比べる と獣医療に関しても経済性が強く要求される。このた め, 犬ブルセラ症並びにB. canis 感染に対してもより効 率的な防疫プログラムを構築する必要があり, その中で 検査と薬剤の選択については経営上特に重要であると考 える．この点に関して今後検討を継続するとともに，新 たな知見が報告されることに期待したい.

検査材料並びに情報の提供にご協力いただいた担当獣医師並 びに施設のスタッフの方々に深謝する。

\section{引用 文 献}

[1] Carmichael LE : Abortions in 200 beagles, J Am Vet Med Assoc, 149, 1126 (1966)

[2] Yamauchi G, Suzuki T, Nomura T, Kukita Y, Iwaki T, Kazuno Y, Ghoda A : Canine brucellosis in a beagle breeding colony, Jpn J Vet Sci, 36, 175-182 (1974)

[3] 今岡浩一: 犬ブルセラ症の現状と課題, 日獣会誌, 62 , 5-12 (2009)

４４］又吉正直, 屋富祖昇，高木和歌子，工藤俊一：沖縄県で 発生したBrucella canisによる犬の集団流産例，日獣会 誌, 61，59-63 (2008)

[5] Greene CE, Carmichael LE : Canine brucellosis, Infectious diseases of the $\mathrm{dog}$ and cat, Greene $\mathrm{CE}$, ed, 3rd ed, 369-381, Saunders Elsevier, St. Louis (2006)

[6 ] 片岡 康：犬ブルセラ病の現状と清浄化に向けた課題, 日獣会誌，63，740-744 (2010)

[7] Scheftel J : Brucella canis : potential for zoonotic transmission, Compend Contin Educ Pract Vet, 25, 846-853 (2003)

［8］今本成樹, 岩崎 隆, 三好紀彰, 三好喜久雄, 増田国充, 二本松昭宏, 渡辺修一郎, 山下洋平, 射場 満, 今本 三香子, 難波信一, 吉田留理子, 相馬武久：一般病院で の 1,104 頭の犬と繁殖場での 120 頭の犬における抗 Brucella canis 抗体の保有状況, 動物臨床医学，3，96-102 (2012)

[9] Wada T, Handa S, Mohri S : Serological survey on agglutinins to Brucella canis in dogs of the Kyushu district, Jpn J Vet Sci, 41, 339-341 (1979)

[10] Saegusa J, Ueda K, Goto Y, Fujiwara K : A survey of Brucella canis infection in dogs from Tokyo area, Jpn J Vet Sci, 40, 75-80 (1978)

[11] Wanke MM : Canine brucellosis, Anim Reprod Sci, 82-83, 195-207 (2004)

[12] Wanke MM, Delpino MV, Baldi PC : Use of enrofloxacine in the treatment of canine brucellosis in a dog kennel (clinical trial), Theriogenology, 66, 1573-1578 (2006)

[13] Mateu-de-Antonio EM, Martin M : In vitro efficacy of several antimicrobial combinations against Brucella canis and Brucella melitensis strains isolated from dogs, Vet Microbiol, 45, 1-10 (1995)

［14］河口雅登, 斎藤奈美子, 勝川千尋, 相馬武久 : マイクロ タイター法による抗ブルセラカニス凝集抗体の検出並び に，溶血による影響の検討，日獣会誌 64, 957-961 (2011)

[15] Kimura M, Imaoka K, Suzuki M, Kamiyama T, Yamada A : Evalution of a microplate agglutination test (MAT) for serological diagnosis of canine brucellosis, J Vet Med Sci, 70, 707-709 (2008)

[16] de Oliveira MZD, Vale V, Keid L, Freire SM, Meyer R, Portela RW, Barrouin-Melo SM : Validation of an ELISA method for the serological diagnosis of canine brucellosis due to Brucella canis, Res Vet Sci, 90, 425-431 (2011)

[17] Blixenkrone-Moller M, Pedersen IR, Appel MJ, Griot $\mathrm{C}$ : Detection of IgM antibodies against canine distemper virus in dog and mink sera employing enzyme-liked immunosorbent assay (ELISA), J Vet Diagn Invest 3, 3-9 (1991)

[18] Kim S, Lee DS, Suzuki H, Watarai M : Detection of Brucella canis and Leptospira interrogans in canine semen by multiplex nested PCR, J Vet Med Sci, 68, 615-618 (2006)

[19] Hollett RB : Canine brucellosis : outbreaks and compliance, Theriogenology, 66, 575-587 (2006)

[20] Wanke MM, Delpino MV, Baldi PC : Comparative performance of tests using cytosolic or outer membrane antigens of Brucella for the serodiagnosis of canine brucellosis, Vet Microbiol, 88, 367-375 (2002)

[21] Riezu-Boj JI, Moriyon I, Blasco JM, Marin CM, Diaz $\mathrm{R}$ : Comparison of lipopolysaccharide and outer membrane protein-lipopolysaccharide extracts in an enzyme-linked immunosorbent assay for the diagnosis of Brucella ovis infection, J Clin Microbiol, 23, 938-942 (1986)

[22] Araj GF : Update on laboratory diagnosis of human brucellosis, Int J Antimicrob Agents, 36 Suppl 1, S12-S17 (2010)

[23] Parma AE, Santisteban G : Analysis and in vivo assay of $B$. abortus agglutinating and non-agglutinating antibodies, Vet Microbiol, 9, 391-398 (1984)

[24] Flores-Castro R, Carmichael LE : VI. Canine brucellosis; current status of methods for diagnosis, Cornell Vet, 68 Suppl 7, 76-88 (1978) 
Course of Antibody Titers After Administration of Antibacterial Agents in a Breeding Kennel with an Outbreak of Canine Brucellosis Takehisa SOMA* ${ }^{* \dagger}$, Masato KAWAGUCHI and Chihiro KATSUKAWA

* Veterinary Diagnostic Laboratory, Marupi Lifetech Co., Ltd., 103 Fushiocho, Ikeda, 563-0011, Japan

\section{SUMMARY}

Fourteen dogs reared in a breeding kennel where an outbreak of canine brucellosis was identified were shown to be positive for anti-Brucella canis antibodies by microtiter agglutination (MA) and ELISA. After being isolated from antibody-negative dogs, they were administered doxycycline hydrochloride and marbofloxacin. The positive rates of both tests declined until 8 weeks after the start of administration, after which they elevated again to $27.3 \%$ in the MA and $63.6 \%$ in the ELISA at week 16 . These results demonstrate the usefulness of antibody tests for monitoring therapeutic efficacy and also suggest ELISA has high sensitivity in antibody detection. Meanwhile, $66 \mathrm{dogs}$ at the same kennel found to be negative were treated with single-agent administrations of doxycycline hydrochloride, and both antibodies remained negative during the 32-week observation period. On the basis of these results, we concluded that tetracycline monotherapy can provide sufficient prevention of infection in antibody-negative dogs when other appropriate measures are immediately taken, such as isolation of infected dogs and disinfection of the facility.

- Key words : Antibacterial agent, Antibody, Breeding Kennel, Canine brucellosis, PCR.

$\dagger$ Correspondence to : Takehisa SOMA (Veterinary Diagnostic Laboratory, Marupi Lifetech Co., Ltd.)

103 Fushiocho, Ikeda, 563-0011, Japan

TEL 072-753-0335 FAX 072-754-2208 E-mail: takehisa-soma@ds-pharma.co.jp

J. Jpn. Vet. Med. Assoc., 66, 115 120 (2013) 